https://doi.org/10.22363/2312-8674-2019-18-4-938-961

Научная статья / Research article

\title{
Ivan IV and Elizabeth I: \\ The influence of the Tsar's matrimonial endeavours on the development of Russo-English relations
}

\author{
George W.C. Gross \\ King's College London; Virginia Woolf Building, 22 Kingsway, \\ London WC2B 6LE, United Kingdom; george.gross@kcl.ac.uk

\section{Иван IV и Елизавета I: влияние матримониальных проектов царя на развитие русско-английских отношений}

\author{
Джордж Гросс \\ Королевский колледж Лондона; WC2B 6LE, Великобритания, Лондон, \\ ул. Кингсвэй, д. 22, стр. Вирджиния Вулф Билдинг; george.gross@kcl.ac.uk
}

\begin{abstract}
Did Ivan the Terrible ${ }^{1}$ propose a marriage alliance with Elizabeth I of England? Did he ever seek an alternative English bride? Was the Tsar truly serious about an English match? Historians have long been divided on whether Ivan the Terrible ever formally sought out to marry the Queen of England this article reveals that a marriage proposal may indeed have been proffered to Elizabeth I, but was not formally written down. The evidence for this is found by focussing on the contextual background of their relations, the long-term realpolitik of the Tsar with England, including his marriage attempts to a relation of the English Queen in the 1580s, and the work of the ambassador Anthony Jenkinson, as an intermediary between Ivan and Elizabeth. In investigating these points, the close diplomatic relations of the two countries in the late sixteenth century and the extraordinarily favourable trading terms offered by Ivan IV to English merchants in the form of the Muscovy Company will also be examined. In addition, the differences and similarities of the perceptions of the two monarchies will be touched upon ${ }^{2}$. Perhaps most intriguingly for the present, research in this period reveals a time in which the two countries experienced a 'friendliness' in diplomatic and trading relations that has never been repeated since and would seem unthinkable today.

Keywords: correspondence of Ivan the Terrible, Muscovy, Muscovy Company, Richard Chancellor, East India Company, Jerome Horsey, Anthony Jenkinson

For citation: Gross, George W.C. "Ivan IV and Elizabeth I: The influence of the Tsar's matrimonial endeavours on the development of Russo-English relations." RUDN Journal of Russian History 18, no. 4 (November 2019): 938-961. https://doi.org/10.22363/2312-8674-2019-18-4-938-961
\end{abstract}

(C) Gross G.W.C., 2019

This work is licensed under a Creative Commons Attribution 4.0 International License https://creativecommons.org/licenses/by/4.0/

${ }^{1}$ I. De Madariaga, Ivan the Terrible: First Tsar of Russia (New Haven: Connecticut Publ., 2005), 12; C.J. Halperin, "Ivan IV as Autocrat (Samoderzhets)," Cahiers du Monde Russe, no. 55 (2014): 197-213; F. Pryor, Elizabeth I: Her Life in Letters (London: British Library Publ., 2003), 55; B. Bobrick, Fearful Majesty: The Life and Reign of Ivan the Terrible (Montpelier, Vermont: Russian life books Publ., 2014), 364-365.

2 G. Gross, "From London to Moscow coronations: perceptions of monarchy," Systems psychology and sociology, no. 2 (26) (2018): 97-110. 
Аннотация: В статье рассматривается проблема матримониальных намерений русского царя Ивана Грозного, не раз обращавшегося к английской королеве Елизавете I с предложением брачного союза. Прежде всего, на основании выявленных источников и английской историографии выясняется реальность существования этих планов, опровергается существующее в литературе предположение об их мифологичности. При этом прослеживается влияние брачных проектов на развитие русско-английских отношений, устанавливается, что периодическое возвращение Ивана IV к идее династического союза было сопряжено с ухудшением дел как в самой России, так и на международной арене. Возможный брак с английской королевой рассматривался русским монархом как средство не только укрепления собственной власти, но и выхода России из международной изоляции. В статье обращается внимание на то, что развитие тесных дипломатических отношений между двумя странами способствовало предоставлению Иваном IV английским купцам торговых преференций. Это «невиданное» в прошлом и «немыслимое» сегодня «дружелюбие» даже дало основание русским боярам называть Ивана Грозного «английским царем». Деятельность же Московской компании, внесшей немалый вклад в процветание английской экономики, станет ориентиром для многих торговых предприятий, заложивших основу величия Великобритании. Однако после отказа Елизаветы I от предложения «руки и сердца» московского правителя, вызванного, прежде всего, политическими соображениями, а также различным пониманием роли монарха, английские купцы утратили свое привилегированное положение в России, а отношения между двумя странами больше никогда не подымались на уровень, достигнутый в середине XVI в. Следует заметить, что часть исследователей к причинам королевского неприятия брачного проекта относят серьезные цивилизационные различия, существовавшие между двумя странами, проявлявшиеся, например, в многоженстве, жестокосердии и деспотизме русского царя. Интерес представляют и выявленные в статье особенности в восприятии двумя монархами природы своей власти. Так, разгневанный отказом Елизаветы, русский царь упрекал ее за согласие с ограничением королевской власти «торговыми людьми», а свое превосходство видел в самодержавном характере правления.

Ключевые слова: Московская компания, переписка Ивана Грозного, Ост-Индская компания, Джером Горсей, Ричард Ченслер, Энтони Дженкинсон

Для цитирования: Гросс Дж. Иван IV и Елизавета I: влияние матримониальных проектов царя на развитие русско-английских отношений // Вестник Российского университета дружбы народов. Серия: История России. 2019. Т. 18. № 4. С. 938-961. https://doi.org/10.22363/23128674-2019-18-4-938-961

\section{Introduction}

This article will examine the prospective of a series of historians (some from a more academic field than others) that have either suggested the possibility or have categorically written of a marriage proposal between Ivan the Terrible and Elizabeth I of England. We begin, however, with the other side of the coin and the prevailing view. Tolstoy of the Victorian historians regarded such a proposition as 'improbable' and 'entirely without foundation' ${ }^{3}$ - yet Huttenbach's detailed analysis of a potential Anglo-Russian alliance raised serious doubts about the validity of resting any argument on Tolstoy's work - 'the material pertaining to the Anglo-Russian treaty presented by Tolstoy is unacceptable and that all works based upon his editions must be considerably revised.' ${ }^{4}$ Lubimenko acknowledged Ivan's plan for an English match in the 1580s with Lady

${ }^{3}$ G. Tolstoy, Pervyye sorok let obshcheniya mezhdu Angliyey i Rossiyey 1553-1593 (St. Petersburg, 1875), 35-36.

${ }^{4}$ H.R. Huttenbach, "New Archival Material on the Anglo-Russian Treaty of Queen Elizabeth I and Tsar Ivan IV," The Slavonic and East European Review, no. 49 (1971): 540. 
Mary Hastings but does not reference a marriage proposal with Elizabeth I - asserting importantly the very 'different motives' and 'aspirations of [the] different monarchs. ${ }^{5}$ Pavlov, Perrie, Skrynnikov and Keenan, all show that Ivan was in close and secret communication with the Tudor queen in the 1560s, using the diplomat Anthony Jenkinson, on a matter of political asylum, but do not go so far as to include talk of marriage. ${ }^{6}$ Mayers is more forceful in setting out that 'there is no remaining direct evidence' for a proposal to Elizabeth $\mathrm{I} ;{ }^{7}$ and Doran does not cover Ivan the Terrible or view him as a potential suitor. ${ }^{8}$ Bertolet has it that there was no chance of a more formal alliance or indeed a marriage union, because the two monarchs spoke a very different language for successful diplomatic relations, let alone marital discussions. There was the problem of mother tongues and varying forms of rhetoric, for

the two monarchs repeatedly misunderstood each other because their writing was a product of different rhetorical systems. ${ }^{9}$

Without a shared mutually understood form of formal conversation, 'neither communicated in a manner wholly understood by the other.' ${ }^{10}$ Yet, this tale has a similar feel to accusations levelled against George I of England in 1714 and his supposed inability to relate to his court and subjects because he spoke German (a lesser point as the language of the courts of Europe involved French). ${ }^{11}$ All this being said, diplomatic languages came in different forms, in this case Latin and Greek were more frequently used and much rested on the success of translators/interpreters. Of course, a question of rhetorical devices mattered, but we know that Ivan had a successful and longstanding friendship with Jenkinson, so did he really so misunderstand Elizabeth? Were they both so naive? This seems too simplistic an understanding of diplomatic relations, not least because for over ten years Anglo-Russian relations were raised to heights never again repeated and even after Ivan's rage in the 1570s towards the Muscovy Company, he renewed talks in the 1580 s and sought out an English marriage with a relation of the queen. Language barriers did not prevent the English mercantile community flourishing in Moscow, nor indeed across the world. The same can be said for the Dutch. So, we must turn to other explanations.

5 I. Lubimenko, "The Correspondence of Queen Elizabeth with the Russian Czars," The American Historical Review, no. 19 (1914): 528-530.

${ }^{6}$ A. Pavlov, and M. Perrie, Ivan the Terrible: Profiles in Power (London: New York University, 2013), 137; E.L. Keenan, "Ivan the Terrible and His Women," Russian History, no. 37 (2010): 341; R.G. Skrynnikov, Ivan the Terrible (Florida: Academic International Press Publ., 1981), 105. See also J.H. Appleby, "Jenkinson, Anthony (1529-1610/11)," in Oxford Dictionary of National Biography.

${ }^{7}$ K. Mayers, North-East Passage to Muscovy: Stephen Borough and the First Tudor Explorations (Stroud: Sutton Publ., 2005), 125.

8 S. Doran, Monarchy and Matrimony. The courtships of Elizabeth I (London: Routledge Publ., 1996); S. Doran, Elizabeth I and Her Circle (Oxford: Oxford University Press Publ., 2015); S. Doran, Elizabeth I and Foreign Policy, 1558-1603 (London: Routledge Publ., 2000).

9 A.R. Bertolet, "The Tsar and the Queen: 'You Speak a Language that I Understand Not'," in C. Beem, The Foreign Relations of Elizabeth I (London: Springer Publ., 2011), 102.

10 Ibid., 104.

11 J. Black, The Hanoverians: The History of a Dynasty (London: Humbledon Publ., 2004), 43, 59; R. Hatton, George I (New Haven, Connecticut: Yale University Press Publ., 2001), 2. 
This article will reveal from the surviving evidence that a marriage proposal may well have been made and was talked about in diplomatic circles. Not only is this finding important for the study of Anglo-Russian relations in the Elizabethan period, it also points to the outward looking nature of Ivan - both internationally for trade links with England, but also to his serious desire for a formal alliance. Whilst this article indicates that many historians have overlooked this important piece of evidence and failed to view it in the long-term context of Ivan's relations with England, the marriage proposal, probably delivered orally by Jenkinson, was nevertheless turned down - indeed seemingly disregarded altogether by Elizabeth. Doran's extensive analysis on Elizabeth's main suitors, while ignoring the possibility of Ivan, nevertheless points in several ways to why a Russian match would most likely have failed with the English Queen. This important work highlights differences in perceptions of rule between the two monarchs.

Unlike the Tsar, Elizabeth had a 'sensitivity to public opinion and an awareness of what was politically possible'. She was not in Doran's view a 'tyrannical ruler who would ride roughshod over the views of the political nation.' Perhaps, even more importantly, she was a pragmatist, and was well '[a]ware of her own limitations' and thus took 'counsel, reject[ing] controversial matches' and therefore remained unmarried. ${ }^{12}$ On two occasions she nearly ventured into a serious union, once with Robert Dudley, Earl of Leicester $(1532 / 3-1588)^{13}$ and then in 1579 when 'her political intuition falter[ed]', but this was a passing phase, and the Queen 'soon recovered and stepped back from the brink of the disaster which would surely have accompanied the Anjou marriage. ${ }^{\prime 4}$ This gap between these two most serious marriage considerations for Elizabeth was roughly twenty years.

Elizabeth's relationship with Leicester was 'unique,' and according to Doran 'based on mutual affection and probably love.' The earl 'owed everything to his intimacy' with his sovereign and both suffered from the imbalance of traditional 'gender roles.' The Queen's position ultimately would not permit a fully-fledged romance with marriage as the end game; and Leicester was forever 'dependent on her favour' and bound by the commands of a woman. ${ }^{15}$

The emotional attachment and blow of the match to the Duke of Anjou, the youngest son of Henri II of France and Catherine de Medici, was all the more difficult. Perhaps because Elizabeth may well have viewed it as her last serious chance. This would have created an alliance that would have brought England and France together against the wishes of her political advisors. As Starkey points out, the Queen was not too dissimilarly aged to her late half-sister Mary I, when she had married Philipp II of Spain. Yet, Elizabeth 'recollected herself' and unlike her predecessor, was not prepared to defy 'both her people and her council.'16

Ivan had none of Elizabeth's pragmatism. His rule was tyrannical, and he rarely listened to the political nation or counsel. Indeed, his creation of the Oprichnina

${ }^{12}$ S. Doran, Monarchy and Matrimony, 218.

${ }_{13}$ D. Starkey, Elizabeth: Apprenticeship (London: Vintage Publ., 2000), 314; S. Adams, "Dudley, Robert, Earl of Leicester (1532/3-1588)," Oxford Dictionary of National Biography.

${ }^{14}$ S. Doran, Monarchy and Matrimony, 218.

${ }^{15}$ S. Doran, Elizabeth I, 141.

${ }^{16}$ D. Starkey, Elizabeth: Apprenticeship, 315-316. 
was a total rejection of the political elite in Russia and the status quo. Even his English friend Jenkinson reported of the horrors he witnessed in 1571, some of unfortunate natural occurrence in 'plague,' but others created by this most capricious of rulers, that Russia has been afflicted in

many ways; first by famine, that the people have been forced to eat bread made of [the] bark of trees, and it is reported that in some places they have eaten one another. Also, the Prince has by sundry torments put to death a great number of his people, chiefly of his nobility, gentlemen, and principal merchants. ${ }^{17}$

Nevertheless, both monarchs had undergone considerable ordeals as children, and had a clear 'instinct for survival' - however, they chose to go about that in very different ways. $^{18}$

\section{Anglo-Russian relations in the 1550s - The Muscovy Company}

We now turn to the beginnings of Anglo-Russian relations for the contextual background to the diplomatic relations of Elizabeth and Ivan. While both countries had some form of understanding of each other's existence before $1553,{ }^{19}$ the formal communications that began in the summer of that year with England was entirely 'unexpected. ${ }^{20}$ It was 'as so many discoveries tend to be ... an accident, or, to be more precise, a result of an error.' ${ }^{21}$ Under the command of Sir Hugh Willoughby, three ships set sail from Gravesend (Kent) in May 1553 with the aim of discovering a north-east route or passage to China. It should not be underestimated just how adventurous, ambitious, and remarkable a sailing feat this was. The mission was financed by London merchants - as ever merchant and thus private funding led the way in England - but this expedition also had royal assent from the court of Edward VI. The Edward Bonaventure managed by the pilot-general of the expedition Richard Chancellor and Willoughby's the Bona Speranza and the Bona Confidentia made good progress reaching the North Cape, the northern coast of Magerøya in Northern Norway (Western Finnmark). ${ }^{22}$ At this point tragedy struck and the vessels were scattered by a storm. The Bona Speranza and Bona Confidentia eventually reunited and opted to harbour in a northern Norwegian fjord, sealing their fate. The crew perished in the Arctic winter either from freezing or more probably, 'carbon monoxide poisoning', from making a fire below-deck using sea coal and then battening-down the hatches, thereby preventing

17 The National Archive (UK), 70/147, fol. 413 r. - 416 v.; A.J. Crosby, Calendar of State Papers Foreign: Elizabeth, 1569-1571 (London: Her Majesty's Stationery Office Publ., 1874), 500-520.

18 S. Doran, Monarchy and Matrimony, 218.

19 K. Mayers, North-East Passage, 113; J.D. Clarkson, A History of Russia (London: Random House Publ., 1961), 130.

${ }^{20}$ I. De Madariaga, Ivan, 121.

${ }^{21}$ A.R. Bertolet, "The Tsar and the Queen,"102.

${ }^{22}$ British Library, Cotton MS Otho E VIII, fol. 11 r. - 16 v.; K. Mayers, North-East Passage, 53-64; I. Grey, Ivan The Terrible (London: Hodder \& Stoughton Publ., 1964), 127-28; F.J. Stout, Exploring Russia in the Elizabethan commonwealth: The Muscovy Company and Giles Fletcher, the elder (1546-1611) (Manchester: Manchester University Press Publ., 2015), 18-20; D. MacCulloch, The Boy King: Edward VI and the Protestant Reformation (Berkeley, California: University of California Press Publ., 2002), 11; S. Alford, London's Triumph: Merchant Adventurers and the Tudor City (London: The Spectator Publ., 2017). 
proper ventilation..$^{23}$ The Edward Bonaventure led by Chancellor, failing to find the other two ships, carried on the dangerous route, alone, eventually ending up in the White Sea. They would discover the demise of their friends on their return voyage. Assisted by the brilliant sailor Stephen Borough, the Edward Bonaventure eventually arrived at St Nicholas on 24 August 1553, near Arkhangelsk (Archangel) via the Dvina river, and opted to stop at this point, to winter in the security of the harbour, while Chancellor set-off overland to meet the ruler of this new-found country. His journey would take him to the capital Moscow, accompanied by various locals. This first encounter must have been quite extraordinary, and we can only imagine, given the language barriers, that early communication would have been via Latin or Greek for the very well educated, or at this early stage and much more likely - hand gestures. ${ }^{24}$ Chancellor was the very first English visitor to Russia and arrived in the capital city in November 1553 . He carried with him a letter of reference, a manuscript of friendship and desire to open trading relations from Edward VI - a remarkable exposition on the merits of free trade. The document was presented to the Tsar.

Edward ... King of England, France, and Ireland, etc. To all Kings, Princes, Rulers, Judges,
and Souernours of the earth ... that every man be freeth to joyne friendship with other,
to love, and to be loved, also to give and receave mutuall benefites ... And if it be right
and equitie to shewe such humanitie toward all men, doubtlesse the same ought chiefly
to be shewed to marchants, who wandering about the world, search both the land and the
sea, to carry such good and profitable things, as are found in their Countreis, to remote
regions and kingdoms, and againe to bring from the same ... commodities for their owne
Countreis ... For the God of heaven and earth, greatly providing for mankind, would not
that all things should be founde in one region, to the ende that one shoulde have neede of
another, that by this meanes friendshippe might be established among all men ... for the
establishing and furtherance of which universall amitie, certaine men of our Realme ...
have instituted and taken upon them a voyage by sea into farre Countreies ... betweene
our people and them, a way may be opened to bring in, \& carry out marchendise, desiring
us to further their enterprise. Who attenting to their petition, have licensed the right va-
liant and worthy Sir Hugh Willoughby, knight, and other our trustie and faithfull servants,
which are with him ... goe to Countreies to them heretofore unknowen, aswell to seeke
such things as we lacke, as also to cary unto them from our regions, such things as they
lacke. So that hereby not onely commoditie may ensue both to them and us, but also ...
perpetuall league of friendship be established between us both ... [.] $]^{25}$

The letter and his first impressions of this traveller from afar, suitably impressed Ivan and he showered his guest with the very best in Muscovite hospitality from within the Kremlin walls. Chancellor was equally enthused, with the warmth of welcome and magnificence of the Russian court, and so the first Anglo-Russian trading conference went as well as could have been imagined. ${ }^{26}$ In February 1554, Chancellor received

${ }^{23}$ K. Mayers, North-East Passage, 67-68.

${ }^{24}$ J. Evans, Tudor Adventures. An Arctic Voyage of Discovery: The Hunt for the Northeast Passage (New York: Pegasus Publ., 2014), 155-156, 162; K. Mayers, North-East Passage, 72-74.

${ }^{25}$ R. Hakluyt, The Principall Navigations... (London: G. Bishop and R. Newberie Publ., 1589), 264-265.

${ }^{26}$ W.B. Turnbull, Calendar of State Papers Foreign: Edward VI 1547-1553 (London: Her Majesty's Stationery Office Publ., 1861), 241 (Ivan IV to Edward VI, Castle of Moscow [the Kremlin], 2 February 1553); R. Hakluyt, Principall Navigations, 283-285; De Madariaga, Ivan, 121-122; I. Grey, Ivan, 128; 
Ivan IV's formal offer and response to Edward VI's letter of reference and request to trade, addressed to 'worthy Edward kinge of England.' As if to utterly illustrate the gulf in locations and the vast distance travelled by these English explorers, news of the young sovereign's death had not yet reached the Russian capital. The Tsar would happily welcome English ships and following negotiations with one of his ambassadors would allow free trade throughout his lands to all English merchants. ${ }^{27}$ Perhaps it was Chancellor's charm, but more likely Ivan was suitably impressed by the bravery of the mission and the connection to this new people from afar, that sought not war, but trade. The seed has been sown and from this first encounter, the Tsar would remain (with some interludes) more-or-less the most committed of Anglophiles of Elizabeth's fellow sovereigns, for the rest of his life.

Ivan's letter would be read by the new Queen of England, Mary I. There was of course considerable disappointment, not only for the loss of the two vessels, but also for the great sadness for lost crew, but additionally because no route had been found to China and the East Indies. Nevertheless, Chancellor had the promising news to bring, of a trading relationship with an almost unknown partner, and without tariffs. Raising fresh funds, the Muscovy Company, a 'fellowship of English Merchants for Discovery of New Trades' set the daring sea captain off to Russia again with two chartered ships. The English merchant world would also have been aware of the miraculous advantage they had achieved in this discovery - it promised much in free trade, but it did even more so, because they had got there before the Dutch, their chief rivals in an age of trade and exploration. England was also badly in need of funds as they were struggling economically with a period of recession. ${ }^{28}$

While the City of London's merchants turned eastward, Ivan had become 'obsessed with the thought of England,' and his trading and diplomatic interests turned westward. ${ }^{29}$ Both countries had an interest in successful relations. Like England, Russia or rather greater Muscovy was surrounded by enemies and 'strategic concerns.' Livonia, ${ }^{30}$ Poland, Lithuania, Sweden and the varying Khanates that had descended from the Golden Horde all threatened the country and limited trade. ${ }^{31}$ Orthodox allies were not in abundance. One hundred and fifty years before Peter the Great and the creation of St. Petersburg, 'the northern passage was a window on to Europe' that avoided 'the only other

C. Andrew, The Secret World: A History of Intelligence (London: Penguin Publ., 2018), 145-57; I. Gralya, Ivan Mikhaylov Viskovatyy: Kar'yera gosudarstvennogo deyatelya v Rossii XVIv. (Moscow: Radiks Publ., 1994).

27 British Library, Add MS 48001, fol. 463 r. - v.; G. Tolstoy, Pervyye sorok let obshcheniya mezhdu Angliyey i Rossiyey 1553-1593, 7-8; R. Pipes, Russia under the Old Regime (London: John Murray Publ., 1995), 198; H. Troyat, Ivan the Terrible (New York: Dorset Press Publ., 1987), 88.

${ }^{28}$ G. Davies, "The Expansion of Trade and Finance, 1485-1640," in G. Davies, History of Money (Cardiff: University of Wales Press Publ., 2002), 195-204; D. Hoak, "The Secret History of the Tudor Court: The King's Coffers and the King's Purse, 1542-1553," Journal of British Studies, no. 26 (1987): 226-227; J. Alsop, "The Revenue Commission of 1552," The Historical Journal, no. 22 (1979): 511-533; J. Oldland, "The allocation of merchant capital in early Tudor London," The Economic History Review, no. 63 (2010): $1058-1080$.

${ }^{29}$ H. Troyat, Ivan, 88.

${ }^{30}$ Lands that had once formed the feudal ancient order of the Teutonic Knights - that would now form parts of present-day Estonia and Latvia.

31 A.J. Crosby, Calendar of State Papers Foreign, 504. 
means of access to the West via the ports in the Baltic Sea.' ${ }^{32}$ So too England lacked friends, with Spain and France ever menacing threats, and the religiously friendly Dutch (during Edward VI and Elizabeth I's reigns) a serious competitor to international trade. Muscovy needed arms, ammunition and saltpetre (for their endless military conflicts) and had further interest in importing cloth, silk, dishes, copper, lead, spices and sugar. English merchants could provide the above, and were keenly interested in furs, fish, timber, tar, skins, hemp, flax and tallow. ${ }^{33}$

Thus, in 1555, Richard Chancellor (this time accompanied by George Killingworth and Richard Gray, Mercantile agents) set sail for Russia in the Edward Bonaventure and the Philip and Mary. The master sailor Stephen Borough would travel out again in $1556 .{ }^{34}$ The intrepid Chancellor and his fellow agents, now from the fully incorporated Muscovy Company by Royal Charter, had been authorised with the power to set-up a charter for trade with Ivan IV and carried again a letter of reference from his sovereign (now Mary Tudor) ${ }^{35}$ The Tsar welcomed his English friend and the letter from his 'very dear sister Mary' and signed an extensive trading agreement 'authorizing English subjects to trade freely in all the towns of Russia without being molested and without paying any duties. ${ }^{36}$ The basis for a comprehensive free trade agreement had been established. To cement the link Ivan sent the first ambassador of Muscovy to London, Osip Napeia, with Richard Chancellor on his return voyage setting out at the end of July 1556 - this time at the head of 'five richly laden ships. ${ }^{37}$ As if to outline the perils of this new sea route, and the dangers for early modern shipping, a large squall disrupted the vessels, separating them on the north-east coast of Scotland, and worse, sending them onto the rocks, and destroying nearly all of the homecoming expedition, apart from the Edward Bonaventure. Many of the sailors drowned, along with much of the precious cargo, and Chancellor was to lose his life having saved that of the Russian ambassador. Despite having lost his precious luggage, Napeia was greeted with great solemnity at the court of Mary I and Philip II of Spain. ${ }^{38}$ The ambassador was presented with 'a gold chain valued at one hundred pounds sterling, and accepted as a gift for his master iridescent fabrics, costly weapons, a lion and a lioness. ${ }^{39}$ His account of his time in London reveals much of the advanced, prosperous nature of the city in contrast to Moscow of the sixteenth century. Crucially, for Ivan, Napeia also acquired numerous specialists in medicine, crafts and munitions, that he would bring with him to Russia. The ambassador travelled back to Moscow in May 1557,

${ }^{32}$ O. Dmitrieva, "Introduction: 'The Golden Chain of Traffic:' The First Hundred Years of AngloRussian Relations," in O. Dmitrieva, and N. Abramova, Britannia and Muscovy: English Silver at the Court of the Tsars (New Haven, Connecticut: Yale Centre for British Art Publ., 2006), 19.

33 O. Dmitrieva, "The First Hundred Years," 20; D. Cressy, "Saltpetre, State Security and Vexation in Early Modern England," Past and Present, no. 212 (2011): 74-111; British Library, Royal MS 13 B I, fol. $127 \mathrm{r} .-\mathrm{v}$.

${ }^{34}$ K. Mayers, North-East Passage, 169-170 (Appendix 6); J. Evans, Tudor Adventurers, 258-261.

35 I. Grey, Ivan, 129.

${ }^{36}$ H. Troyat, Ivan, 90; O. Dmitrieva, "The First Hundred Years," 19

${ }^{37}$ H. Troyat, Ivan, 90.

38 E.D. Morgan, C.H. Coote, Early Voyages and Travels to Russia and Persia by Anthony Jenkinson ... with Russia ... by way of the Caspian Sea (London: Hakluyt Society Publ., 1886); I. De Madariaga, Ivan, 126.

39 H. Troyat, Ivan, 90. 
this time escorted by the first English ambassador to the Muscovite court, that of Anthony Jenkinson. Ivan was 'flattered,' particularly with letters presented to him by Napeia, from Mary Tudor referring to the Tsar as the 'august Emperor.' ${ }^{\prime 0}$ This recognition of status played extremely well with the ruler that was the first grand prince of Muscovy to be crowned tsar. ${ }^{41}$ This perception of monarchy was critical in these first diplomatic relations and Ivan was appositely flattered. He wanted to be viewed as a Tsar - an Emperor and this communication gave credence to his ambitions.

Thus, a firm setting had been made for reciprocity in trade charters and diplomatic talks - a direct line for dialogue had been secured between the two distant lands. ${ }^{42}$ Jenkinson developed a strong working relationship with the Tsar and would widen English trading horizons, to Astrakhan, Bokhara (along the silk route) and into Persia. ${ }^{43}$ With the approval and admiration of Ivan, Jenkinson's 'ventures' were granted 'extensive privileges' and the Muscovy Company had an almost complete 'monopoly' of European trade with Russia ${ }^{44}$. The English agent would play a crucial role in developing Anglo-Russian relations in the early years of Elizabeth I's reign. Yet crucial to successful relations, were the communications between rulers, for State diplomacy in the early modern world was in many ways perceived as a personal dialogue between reigning monarchs. The anglophile Ivan IV and Elizabeth I, who succeeded her sister Mary in [November] 1558, justified such a perception for they maintained a regular correspondence of striking intensity. ${ }^{45}$

\section{Elizabeth I and Russia - the early years}

Diplomatic relations blossomed between the anglophile Tsar and the new Queen of England. Ivan wanted 'friendshipp' and hoped that they would be 'good ... rulers together.' ${ }^{46}$ Nevertheless, the trading arrangements between the two countries certainly appear to

${ }^{40}$ H. Troyat, Ivan, 90-91; British Library, Cotton MS Nero B VIII, fol. 3 r. - v.

${ }^{41}$ Ivan IV would formally adopt the title of Tsar, and a coronation service based on Byzantine tradition to suitably match this status - for a coronation and the accompanying ritual was a legitimisation par excellence. The tsar wore the Monomakh regalia, often referred to as 'The golden cap', this crown is the oldest part of the Russian regalia, http://old.kreml.ru/en/virtual/exposition/regalia/Monomach; S. Sebag Montefiore, The Romanovs (London: Weidenfeld a. Nicolson Publ., 2016), 14; B.A. Uspenskiy, "Enthronement in the Russian and Byzantine Traditions," in B. Uspenskiy, and V. Zhivov, Tsar and God (Boston, Massachusetts: Academic Studies Press Publ., 2012), 153; R.S. Wortman, Scenarios of Power: Myth and Ceremony in Russian Monarchy from Peter the Great to the Abdication of Nicholas II (Princeton, New Jersey: Princeton University Press Publ., 2006), 10-11; S. Bogatyrev, "Bronze Tsars: Ivan the Terrible and Fedor Ivanovich in the Décor of Early Modern Guns," The Slavonic and East European Review, no. 88 (2010): 57-58; S. Bogatyrev, "Reinventing the Russian Monarchy in the 1550s: Ivan the Terrible, the Dynasty, and the Church," The Slavonic and East European Review, no. 85 (2007): 273; L. Hughes, "Russia: The Courts at Moscow and St. Petersburg. 1547-1725," in J. Adamson, The Princely Courts of Europe: Ritual, Politics and Culture Under the Ancien Régime 1500-1750 (London: Seven Dials Publ., 1999), 295; A.M. Kleimola, and G.D. Lenhoff, Moskovskaya Rus'(1359-1584): kul 'tura i istoricheskoye samosoznaniye (Moscow: ITS-Garant Publ., 1997), 179-80; National Library of Scotland, Adv. MS 33.2.26, fol. 96 r. - 101 v.

42 The National Archives, PRO 22/60, fol. 3.

${ }^{43}$ British Library, Royal MS 13 B I, fol. 49 r. - v.; H. Troyat, Ivan, 136; A. Pavlov, M. Perrie, Ivan, 137; C. Raymond Beazley, "Exploration under Elizabeth, 1558-1603," Transactions of the Royal Historical Society, no. 9 (1895): 132; F. Pryor, Elizabeth I, 45.

${ }_{44}$ I. Grey, Ivan, 129; The National Archive (UK), SP 70/147, fol. 269.

45 O. Dmitrieva, "The First Hundred Years," 19.

46 British Library, Cotton MS Nero B VIII, fol. 16 v. 
have considerably favoured the English merchants. Grey's reading of this was that Elizabeth encouraged her trading base and gave little in the way of reciprocity - the Queen 'actively supported her merchants in extracting every advantage and yielding as little as possible in return.' Whilst Russian merchants, sailing with the Muscovy Company 'were exempted aliens' dues', they 'enjoyed no other privileges. ${ }^{47}$ Yet, this analysis, does not quite fit the situation. Ivan was not so naive. He needed military imports more than he needed to export his goods. He had few international allies and this trading imbalance was worth the weight of the arms he received to carry on his military operations. Surrounded by enemies, Russia was in many respects under blockade. The White Sea, non-Baltic route, was a means of defeating this obstacle. It should be noted that Muscovy was involved in almost continuous military conflict during Ivan's reign with one or more of its various neighbours and Ivan 'became known in the West as a powerful monarch who conquered' both 'Kazan and Astrakhan. ${ }^{48}$ The Livonian wars of the 1560s were perhaps the most complex diplomatically. ${ }^{49}$ While the Muscovy company expanded and flourished, Ivan's demands grew, and in this, he either did not care, or was unaware of the delicate path Elizabeth had to follow to avoid upsetting England's diplomatic neighbours. Denmark, Poland and Sweden had all complained about the supply of arms to Muscovy from London and the use of English expertise.

In 1561 the Senates of Cologne and Hamburg even stopped shipments of arms to England, until the Queen gave assurances that such arms were for her own use not for reshipment. ${ }^{50}$

Elizabeth played a very careful hand, particularly as English Baltic shipping was continuously under observation and sometimes even unwarranted arrest and seizure. ${ }^{51}$ She was almost certainly not telling the full truth. Somehow Ivan continued to receive military supplies, but England avoided being drawn into the theatre of Baltic wars. This did not diminish the frequency of correspondence. The Elizabethan reign saw more than one hundred items of communication of differing forms and over 'sixty [that would] ... qualify as personal letters, half of those being addressed to Ivan IV and half to Fyodor Ivanovich and Boris Godunov. ${ }^{52}$ These years would also see a tremendous quantity of English silver presents that remain in the Kremlin to this day. ${ }^{53}$ Yet what of the relations between the Tudor monarch and Tsar of Russia - Ivan IV? Was a closer union ever sought?

47 I. Grey, Ivan, 130.

48 S. Bogatyrev, "Bronze Tsars," 71.

49 I. De Madariaga, Ivan, 123-41, 189-205; A. Filyushkin, Ivan the Terrible: A Military History (Barnsley: Frontline Books Publ., 2008), passim.

${ }_{50}$ I. Grey, Ivan, 130; British Library, Royal MS 13 B I, fol. 56 v.

51 British Library, Royal MS 13 B I, fol. 230 r. - v.; fol. 3 v.; fol. 71 v.

52 O. Dmitrieva, "The First Hundred Years," 19; I.I. Lubimenko, "Correspondence of Queen Elizabeth with the Russian Czars," 525-542; I.I. Lubimenko, "A Suggestion for the Publication of the Correspondence of Queen Elizabeth with the Russian Czars," Transactions of the Royal Historical Society, no. 9 (1915): 111-122; The National Archive, PRO 22/60, fol. 7.

${ }_{53}$ N. Abramova, "English Silver of the Sixteenth and Seventeenth Centuries in the Kremlin," in O. Dmitrieva, and N. Abramova, Britannia and Muscovy: English Silver at the Court of the Tsars (New Haven, Connecticut: Yale Centre for British Art Publ., 2006), 36-45; I. Zagorodnaya, "English Diplomats at the Court of the Tsars," in O. Dmitrieva, and N. Abramova, Britannia and Muscovy: English Silver at the Court of the Tsars (New Haven, Connecticut: Yale Centre for British Art Publ., 2006), 176-195; C. Oman, The English Silver in the Kremlin, 1557-1663 (London: Methuen Publ., 1961); "Muzei Moskovskogo Kremlya. 


\section{Elizabeth I and Ivan IV - personal relations - marriage?}

While Ivan became ever more obsessed with England and acquired from his more xenophobic boyars the title 'English Tsar,' what was Elizabeth's feelings towards the Russian sovereign? ${ }^{54}$ Formally, the royal correspondence between the two rulers was set-out in affectionate and respectful terms, Elizabeth was 'our sister Elizabeth' and 'dear sister,' while Ivan was an Emperor and a great Duke and 'dear and loving brother. ${ }^{55}$ Yet, this private flow of communication was an 'active political instrument' guided by the development and prospects of the Muscovy Company. Elizabeth set her stall on those interests, while Ivan's 'unpredictable moods and more deep-rooted political factors' both at home and abroad hugely impacted Anglo-Russian relations. ${ }^{56}$

There has been much speculation as to what drove Ivan's changes in character. Just as the 'terrible' tsar has been compared to Stalin for his savagery to his own people, so the comparison also rests on the demise of his first wife Anastasia Romanovna Zakharina-Yurieva (c. 1530-60) ${ }^{57}$ and that impact on him, and so likewise the death of Stalin's second wife Nadeszda (née Alliluyeva). ${ }^{58}$

Ivan IV married for the first time in 1547, and the marriage appears to have been a happy one, bringing him six children, and two surviving male heirs, Ivan and Fyodor (the future Tsar Feodor I of Russia, last of the Rurikid dynasty).$^{59}$ Anastasia's death took with her the one person who appeared to have 'the gift of being able to calm his manic temperament. ${ }^{60}$

The demise of his first wife brought forth a series of wives in quick succession. The majority of whom were either sent away to convents or died in unfortunate circumstances. Ivan's apparent overtures to the English Queen were according to some historians made in the late 1560s. It occurred to the Tsar that in an effort to establish a more formal alliance he would solidify the union with an Anglo-Russian match. Hamel, Morgan and Coote of nineteenth century accounts, suggest that this was done 'in the greatest secrecy,' via 'an oral message' taken by Ivan's English confidante Anthony Jenkinson in 1567, soliciting the hand of Elizabeth I. ${ }^{61}$ Sebag Montefiori argues that Anastasia's death unsettled Ivan, and in his mourning, he became 'convinced she

Zarubezhnyy khudozhestvennyy metal," Moscow Kremlin Museums, accessed February 13, 2019, https:// www.kreml.ru/en-Us/about-museums/museum-collection/zarubezhnyy-khudozhestvennyy-metall.

54 O. Dmitrieva, "The First Hundred Years," 19; F. Pryor, Elizabeth I, 55; R. Pipes, Russia, 198; B. Bobrick, Fearful Majesty, 363.

55 British Library, Cotton MS Nero B VIII, fol. 4 r. - 5 v.; O. Dmitrieva, "The First Hundred Years," 19; I.I. Lubimenko, “Correspondence of Queen Elizabeth with the Russian Czars," 531.

56 O. Dmitrieva, "The First Hundred Years," 19.

57 S. Sebag Montefiore, Romanovs, 15; D.B. Miller, "Creating Legitimacy: Ritual, Ideology, and Power in Sixteenth-Century Russia," Russian History, no. 21 (1994): 298; S. Bogatyrev, "Reinventing the Russian Monarchy," 277.

58 S. Sebag Montefiore, Stalin: The Court of the Red Tsar (London: Weidenfeld \& Nicolson Publ., 2003), 93-101, 158, 206, 350; A. Bullock, Hitler and Stalin: Parallel Lives (London: Harper Collins Publ., 1991), 414-416.

59 R.S. Wortman, Scenarios of Power: Myth and Ceremony in Russian Monarchy from Peter the Great to the Abdication of Nicholas II (Princeton, New Jersey: Princeton University Press Publ., 2006), 12.

60 S. Sebag Montefiore, Romanovs, 15.

${ }^{61}$ K. Mayers, North-East Passage, 124-125; J. Hamel, England and Russia (London: Bentley Publ., 1968); E.D. Morgan, C.H. Coote, Early Voyages, II, 257. 
had been poisoned by hostile grandees [boyars],' thus embarking on a 'reign of terror'. Given the 'instability' of his reign, and the fact that his youngest heir did not seem 'strong' (he may have suffered from considerable learning difficulties), it was therefore 'essential to marry again.' Sebag Montefiori draws the comparison with Henry VIII and his 'obsession' with the continuity of his Tudor dynasty and that of marriage. ${ }^{62}$ Beyond Anastasia, and that of his second wife, a Tatar princess,

he sought foreign brides, a princess from the dynasty ruling Sweden and Poland in the hope of winning the Polish throne, and an Englishwoman, possibly even Elizabeth I herself, Ivan worked his way through as many as eight wives, three of whom many have been poisoned, and some of whom may have been murdered on his own orders. ${ }^{63}$

So Sebag Montefiori continues the idea of an Anglo-Russian match with Elizabeth I. This is also the view of Dmitrieva and Abramova. They argue that Ivan put forward the idea of a

military and political alliance between the two countries which would have brought England into the Livonian war [in the 1560s], and - to reinforce that alliance - a dynastic marriage between the Russian Tsar and Queen Elizabeth. In addition, he proposed that the monarchs agree to offer each other refuge in the event that either was forced to flee as a result of internal revolt or intervention from without. ${ }^{64}$

Troyat, though from a less researched and academic standpoint, was as categorical and goes into more detail on the subject. With Ivan's unstable nature and fear of his own people, he turned to a new way of governing, setting up the Oprichnina. ${ }^{65}$ Even with this form of bodyguard, he was so consumed with fear for his own safety that he turned to England for help - considering them 'a natural ally of Russia', and so in an extraordinary appeal (via letter) sought out the possibility of 'asylum in England in case he should have to flee for his life' and a more categorical military alliance. It was a 'humiliating request' for an early modern ruler, yet Ivan did not see it that way. ${ }^{66}$ Pavlov and Perrie, Skrynnikov and Keenan too, frame it in less colourful terms, Ivan was 'afraid of internal unrest' and was 'uncertain of the future and fearful for his own safety' - Jenkinson and England with the 'strong and successful commercial and diplomatic ties' that had developed, were 'not surprising' selections for a negotiation of 'political' sanctuary. ${ }^{67}$ His missive was one of reciprocity, offering asylum to Elizabeth in Russia in case

${ }^{62}$ S. Sebag Montefiore, Romanovs, 16; C.J. Halperin, Ivan the Terrible: Free to Reward \& Free to Punish (Pittsburgh, Pennsylvania: University of Pittsburgh Press Publ., 2019).

63 S. Sebag Montefiore, Romanovs, 16.

${ }^{64}$ O. Dmitrieva, "The First Hundred Years," 20; I. Grey, Ivan, 192.

${ }_{65}$ M. Perrie, "The Popular Image of Ivan the Terrible," The Slavonic and East European Review, no. 56 (1978): 280; H.F. Graham, "How do we know what we know about Ivan the Terrible? (A Paradigm)," Russian History, no. 14 (1987): 179-183; P. Hunt, "Ivan IV's Personal Mythology of Kingship," Slavic Review, no. 52 (1993): 797-800, 807; C. Andrew, Secret World, 141-145.

${ }^{66}$ H. Troyat, Ivan, 136.

${ }^{67}$ A. Pavlov, and M. Perrie, Ivan, 137; E.L. Keenan, "Ivan the Terrible and His Women," 341; R.G. Skrynnikov, Ivan, 105. 
any misfortune might fall or chance upon ether of them to goe out of their countries, that it might be lawfull to ether of them to come into the others countrey for the safegard of them selves and their lyves. ${ }^{68}$

The question is not whether Ivan sought this out, Pavlov and Perrie, Skrynnikov and so too Keenan all concur, it is whether as Hamel, Morgan, Coote, Sebag Montefiori, and Troyat suggest, he went further. Troyat argues that Jenkinson, who presented Ivan's proposals to Elizabeth, also took with him 'a secret message' of marriage to the Queen. ${ }^{69}$ His hypothesis is not unconvincing:

The Queen [Elizabeth I], who had succeeded her half sister Mary, was reported to be a beautiful, intelligent woman, cultivated and strong-willed. Her relations with Ivan had always been extremely courteous. She was thirty-four years old and not married. He was thirty-seven and his wife, the Circassian, had long since ceased to please him. Why not repudiate her and marry the Queen of England? ${ }^{70}$

This theory rests on the premise that Ivan had Jenkinson present two proposals, advancing himself "simultaneously as a possible political refugee and a definite suitor, asking for her hand today and her potential protection tomorrow. ${ }^{71}$ Troyat argues that Ivan's reciprocal offer of 'sanctuary' rested on his view of the code of 'honour,' involving a system of 'exchange' for something received, there should be something given. Therefore, the tsar 'demanded that the Queen agree to settle in the Kremlin in case conspirators should place her life in danger. Needless to say, the daughter of Henry VIII could not agree to this curious bargain and had no reason or desire to leave her country.'72

As Ivan really did ask for asylum and proposed a military alliance, it is not beyond the realms of possibility that he also sought a marriage alliance with Elizabeth. It was well-known that she was unmarried, propagating the Gloriana notion of herself as the virgin Queen and had been courted by Erik XIV. ${ }^{73}$ Ivan was not a reticent monarch and may well have proposed himself as a potential husband. The theory has survived in the historiography precisely because it is a convincing one. Nevertheless, we lack formal documentation of a written proposal.

Whether or not a marriage proposal was discussed, and whether these suggestions from Ivan seemed credible in London on Jenkinson's return to the Tudor court, the tsar had presented them and was serious about them, Elizabeth was thus faced with a dilemma. England was not in a position to join a more formal military alliance with Russia, yet Russia was a very important new trading partner, that had granted her mer-

${ }^{68}$ I. De Madariaga, Ivan, 222; G. Tolstoy, Pervyye sorok let, 38.

${ }^{69}$ H. Troyat, Ivan, 136; I. Grey, Ivan, 192.

70 H. Troyat, Ivan, 136-137.

71 Ibid., 137.

72 Ibid., 138.

73 British Library, Royal MS 13 B I, fol. 20 r. - v.; I. De Madariaga, Ivan, 128, 147; C. Beem, C. Levin, "Why Elizabeth Never Left England," in C. Beem, The Foreign Relations of Elizabeth I (New York: Palgrave Macmillan Publ., 2011): 14; N. Martin, "Princess Cecilia's Visitation to England, 1565-1566," in C. Beem, The Foreign Relations of Elizabeth I (New York: Palgrave Macmillan Publ., 2011): 27; R. Wortman, Myth and Ceremony in Russian Monarchy, 34. 
cantile community remarkable terms of free trade. So too, her trading rivals, particularly the Dutch were pushing Ivan to revoke these favourable terms for the English and open herself up to other European partners. English merchants were also under increasing pressure from Denmark and Sweden over access to the Baltic as an additional and more navigable route to Russian commerce via Livonia. ${ }^{74}$ The Tudor court therefore 'sought to lead the negotiations towards more superficial assertions of friendship and discussions of matters of trade' and Elizabeth did what she so often did in her reign and 'played for time.' 75 If there was a marriage proposal, then she 'had no intention of marrying' ${ }^{\prime 6}$ the Russian Tsar. Ivan's 'the terrible' reputation had not escaped the English, particularly the way he was treating his people - in the most 'cruel' manner (even by Tudor standards) ${ }^{.77}$ Thomas Randolph, the second English ambassador to Russia, reported to Cecil that having completed his mission for the Queen with the tyrannical Ivan, it was best to be 'the sooner ... oute of his [Ivan's] countrie, where heads goe so faste to the potte [!]. ${ }^{78}$ Not only was it known in England of the 'conditions' that Ivan's subjects suffered, and the way their monarch treated his subjects, but the Tsar was also known for his womanizing. ${ }^{79}$ Ivan's cruelty and his many marriages were not likely to be the best of selling features on the wedding stakes. Nevertheless, the Tsar was serious in the hand he played and would have to be handled with careful consideration. However, Elizabeth's delaying tactic and the English approach of focussing purely on their own mercantile priorities while avoiding a move to a closer politico-military alliance, played very badly ${ }^{80}$ with the 'impetuous' tsar and 'aroused Ivan's undisguised ire. ${ }^{91}$

Receiving no answer to his advances, Ivan became angry and opened the port of Narva to other foreigners. The Company grew anxious and turned to the Queen. ${ }^{82}$

Most unfortunately for diplomatic relations, the popular Jenkinson was unable to return to Moscow and so a new ambassador Thomas Randolph, Master of the Queen's Posts was sent in his place, arriving in Moscow in October $1568 .{ }^{83}$ Troyat's view was that Randolph's mission was to fix the trading relations that had been broken for the English mercantile community in Muscovy, whilst, 'avoiding, if possible, the question of marriage. ${ }^{84}$ Ivan maintained a friendly outlook towards England, desiring 'good will and great favour,' even if his relationship with Randolph was not as friendly as that with

74 The National Archive, SP 91/1/122 r.

75 O. Dmitrieva, "The First Hundred Years," 20; H. Troyat, Ivan, 137; I. Grey, Ivan, 192-195.

${ }^{76}$ H. Troyat, Ivan, 137.

77 M. Perrie, "The Popular Image of Ivan the Terrible," The Slavonic and East European Review, no. 56 (1976): 275-286.

78 The National Archive, SP 70/101, fol. $31 \mathrm{r}$.

79 Ibid., fol. 30 v.; I. Grey, Ivan, 150.

${ }^{80}$ The National Archive, SP 102/49, fol. 1 r. - v.; British Library, Cotton MS Nero B XI, fol. 347 r. - 348 v.

${ }^{81}$ H. Troyat, Ivan, 137; O. Dmitrieva, "The First Hundred Years," 20.

${ }^{82}$ H. Troyat, Ivan, 137.

83 Idem.; J.H. Appleby, “Jenkinson, Anthony (1529-1610/11)," in Oxford Dictionary of National Biography; J. Lock, "Randolph, Thomas (1525/6-1590)," in Oxford Dictionary of National Biography.

84 Ibid., 137-138. 
Jenkinson. ${ }^{85}$ In June 1569, an increasingly impatient Tsar sent a cryptic letter to Elizabeth that alludes to a failure on the Queen's behalf to answer his request of his message sent via Jenkinson. Whilst not mentioning marriage in word, it seems odd that Ivan was only alluding to asylum, and indeed felt that he could not refer to an alliance more explicitly in a letter. The Tsar asked of various English messengers sent to him

\begin{abstract}
Whether your, our sisters, messenger Anthonie [Jenkinson] were come to youre presense, and whether you had anie thinge to saie to us of the messaidge, or whether Anthonie should come, or anie other in his stead; and they beinge embrased with pride, would make us no aunswere, that they would not come to our neare and privie counsaile, and would make them privie of none of theire affaires; all that they saide was of marchunt affaires, and settinge our highness affares aside, as it is the use of all countries that princes affaires should be first ended... [.] $]^{86}$
\end{abstract}

Randolph returned to London in the August of 1569, this time with Ivan's envoy Savin. ${ }^{87}$ The new ambassador remained in the English capital for nearly a year and returned to Moscow, carrying Elizabeth's much delayed response to the questions of a military alliance, asylum and possibly a marriage union too. The Queen remained non-committal to a military alliance, stating an interest to join forces 'against our common enemies,' but this was not the same as a defensive and offensive military alliance, and there is no mention of the marriage union. In the end she did offer asylum, but with terms that Ivan would have to pay for his and his retinues costs. In other words, he was welcome, but at his own expense. ${ }^{88}$

If at any time it so mishappe that you L[ord] our brother Emperour and great Duke, bee by anie casuall chaunce either of secrite conspiracie or outward hostillitie driven to change your countries and shall like to repaire into our kingdome and dominions, with the noble empresse your wife and youre deare children the princes, we shall with such honors and curtesies receive and intreate your highnes then, as shall become so great a prince and shall earnestlie endeavour to make all things fall our accordinge to your ma[jes]ties desire, to the free and quiett breedinge of your highnes life, with all those whom you shall bringe with you: and that it maie be lawfull for you the Emperour and great Duke to use your Christian religeon in such sorte, as it shall like you ... Besides wee shall appointe you the Emperour and great Duke a place in our kingdom fitt upon your owne charge, as longe as ye shall like to remaine with us. ${ }^{89}$

Ivan was furious with the Queen's answer, but it is curious that he was so enraged that she had not taken up his offer of asylum. Yes, perhaps, it showed her sense of status, or arrogance in Ivan's eyes, but in keeping with the marriage proposal theory, a rejection

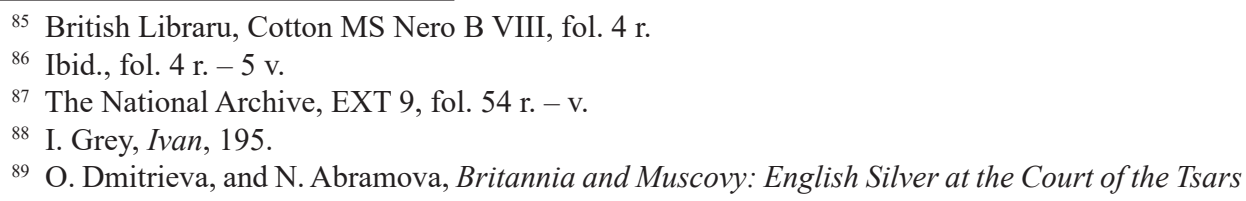
(New Haven, Connecticut: Yale Centre for British Art Publ., 2006), 208-209; RGADA, f. 35, op. 2, d. 3; The National Archive, PRO 22/60, fol. 4; SP 70/147, fol. 375 r. - 378 v.; E.D. Morgan, C.H. Coote, Early Voyages, II, 290-292. 
of marriage might well be the better explanation of his frustration. In other words, rather than 'even a veiled allusion to a possible marriage ... silence!'90

At this point we must turn to the surviving evidence, and an item that has avoided thorough scrutiny in the historiography. Thomas Randolph's report to William Cecil (first Baron Burghley) ${ }^{91}$ reveals precisely this sense of Ivan's unhappiness with the absence of a response to a possible marriage proposal. His communique for 12 August 1568 states that he finds

one matter I finde ... aggravated against Jenkinson is I believe ... as though he should have dealte with that prince in some matter of marriage either with this Emperour ... or with his son[.] ${ }^{92}$

This passage goes on to describe Ivan's atrocities to his own people and is often cited for those atrocities, but historians have studiously avoided this earlier reference to marriage. Isabel de Madariaga gives some credence to this talk of marriage but does not provide this important contemporaneous evidence. ${ }^{93}$ At the very least these findings show the thoughts of Randolph - a product of his meetings with the Tsar, of rumours, discussions and general diplomatic 'tittle-tattle' that existed contemporaneously. This is not concrete proof, but it would explain Ivan's furious response to Elizabeth's reply.

Of course, it was perhaps insulting to offer asylum at the tsar's own expense, but then again, for early modern comparison, Charles II in the 1650s in France, and the Jacobites in Rome and continental Europe, were given asylum, but struggled on with little in the way of funds from the sitting monarchs and rulers. Although the situation was at times iniquitous, those in exile were only too grateful to have a safe haven. By modern comparison a genuine offer of asylum was considerably more than Tsar Nicholas II would ever receive in 1917, with or without expenses. ${ }^{94}$ One should also consider that the Elizabethan finances were far from plentiful and the cost to the exchequer of a fellow monarch with all his retinue would have been exorbitant. Thus, while Ivan may have been insulted by what he saw as an ungenerous offer of asylum, it was more likely to be a combination of reasons, and the absence of any mention of marriage that so frustrated the Tsar, and this would better fit with the surviving evidence of Randolph's most interesting revelation to Cecil.

Nevertheless, for all of these points, Ivan was enraged and in a form or retaliation 'revoked the Company's privileges and sequestered its goods. ${ }^{95}$ The incandescent tsar accompanied this with a furious letter, suggesting that Elizabeth was only Queen in name, and was ruled by a group of advisors, and that her inability to form a clear

${ }^{90}$ H. Troyat, Ivan, 139.

91 W.T. MacCaffrey, "Cecil, William, first Baron Burghley (1520/21-1598)," in Oxford Dictionary of National Biography.

92 The National Archive, SP 70/101, fol. $30 \mathrm{v}$.

93 I. De Madariaga, Ivan, 237, 285.

94 F. Welch, The Imperial Tea Party. Family, Politics and Betrayal: The Ill-fated British and Russian Royal Alliance (London: Short Books Publ., 2018), 237-246; H. Rappaport, The Race to Save the Romanovs: The Truth Behind the Secret Plans to Rescue Russia's Imperial Family (London: St. Martin's press Publ., 2018), 106-110; R. Service, The Last of the Tsars: Nicholas II and the Russian Revolution (London: Pan Books Publ., 2017), 69; H. Rappaport, Caught in the Revolution: Petrograd 1917 (London: Windmill Books Publ., 2016), 136.

${ }_{95}$ I. Grey, Ivan, 195; H. Troyat, Ivan, 140. 
decision rested in her femininity. ${ }^{96}$ English merchants and diplomats suffered as a consequence of the breakdown in realpolitik between the two sovereigns and their advisors, and 'over the next years ... were to feel all the force of the Tsar's anger and that of his administration.' ${ }^{97}$ Correspondence between Ivan and Elizabeth turned decidedly unfriendly - Ivan complained that

\begin{abstract}
wee had thought that you had beene ruler over your lande and had sought honor to your self and and proffitt to your Countrie, and therefore wee did pretend those w[e]ightie affairs between you and us. But now wee perceive that there be other men that doe rule, and not men, but bowers [i.e. boyars or nobles] and marchaunts, the w[h]ich seeke not the wealth and honnor of our majesties, but they seke there owne proffitt of marchandize. And you flowe in your maydenlie estate like a maide; and whosoever was trusted in our affaires and did deceave us, it were not meete that you should creditt them. And now seeinge it is so, wee doe sett aside those affaires; and those bowrish Marchaunts that have beene the occasion that the pretended welthes and honors of our Majesties hath not pretended welthes and honors of our Majesties hath not come to passe, but doe seeke their owne wealthes, they shall see what traffique they shall have here; for our cittie of Musko [Moscow], before their traffique to it, hath not greatly wanted Englyshe commodities. And the priviledge that wee gave to your Marchaunts, and sent to you, that you would send it us againe, and whither it be sent or no, wee will give commaundement that nothing shalbe donne by it. And all those priviledges $\mathrm{w}[\mathrm{h}] \mathrm{ich}$ wee have given aforetime be from this daie of none effect $\ldots[.]^{98}$
\end{abstract}

What had previously been a pleasure for Ivan, was now a pain, the once special trading relationship was not viewed in the same light when he could not achieve the form of alliance, he so desired with Elizabethan England. The Muscovy company fared very badly from this and found that their trading posts and routes, factories, properties and land were taken over by the oprichniki. Worse still, they discovered that the door had been opened to their European competitors. ${ }^{99}$ Towards the end of the $1570 \mathrm{~s}$, the true 'cooling in Anglo-Russian relations' was made paramount as 'Dutch ships sailed into the mouth of the River Dvina' - thus cementing a Dutch position in Russian trade. ${ }^{100}$

Diplomatically, Ivan had failed to achieve the more formal defensive and offensive military alliance that he had sought, and Russia looked isolated in the early 1570 s, as Denmark, Poland and Sweden all ceased their military disputes between each other, giving rise to the very real prospect of a Baltic alliance against Russia that could include a trading embargo of the Baltic sea. ${ }^{101}$ Elizabeth sent Anthony Jenkinson back to Russia in 1571-1572 to try and repair the damage of Randolph's visit, and although relations improved a little, the Tsar continued to press for answers on his 'secret message' - reference to his plans for a military alliance, asylum and some form of marriage proposal. Jenkin-

96 The National Archive, SP 70/147, fol. 440 r. - 443 v.; K. Mayers, North-East Passage, 125; I. Grey, Ivan, 195; R. Pipes, Russia, 77.

${ }_{97}$ O. Dmitrieva, 'The First Hundred Years,' 20.

98 The National Archive, SP 102/49, fol. 1 r.; British Library, Cotton MS Nero B XI, 347 r. - 348 v.; A.J. Crosby, Calendar of State Papers Foreign, 500.

99 A.J. Crosby, Calendar of State Papers Foreign, 504; R. Pipes, Russia, 198.

100 O. Dmitrieva, "The First Hundred Years," 21.

101 A.J. Crosby, Calendar of State Papers Foreign, 386. 
son as his dispatches record was non-committal with the Tsar, after-all Elizabeth had not equipped him with much to heal relations. ${ }^{102}$ Ivan in turn continued to press Elizabeth for answers, without success. Diplomatic ties were never fully broken, and Daniel Sylvester (ambassador) made several missions to the Russian court in the mid-1570s, but without much success. ${ }^{103}$

\section{Marriage again? Mary Hastings, daughter of Lord Huntingdon}

For all of the failings in diplomatic relations in the late 1560 s and early 1570 s, Ivan IV could never quite forget England. In 1581, roughly eleven years from his supposed proposal, this anglophile tsar, turned to London again for a marriage alliance. One says 'again', but much of the historiography would have this as for the first time. On this occasion the tsar "was actually married to his seventh wife, ${ }^{104}$ though he claimed that union had no legal status' and sought the hand not of the Queen, but of a close relation ('niece'), Lady Mary Hastings. ${ }^{105}$ At the time, Ivan had with him at court an English doctor, Robert Jacob, ${ }^{106}$ an ambassador of sorts, part doctor, part envoy, who put forward the name of the daughter of the Earl of Huntingdon, a relation of Elizabeth I, as a suitable match. ${ }^{107}$ Thus in 1582, Ivan formally resumed contact with the Queen of England via the Muscovy Company and in this instance the head of the operation, Jerome Horsey. ${ }^{108}$ Acting for the Tsar in London was an envoy of the Russian court, Fedor Pisemsky. ${ }^{109}$ Pisemsky was given orders to propose a military alliance on similar terms as those a decade before and in addition, a marriage union with a relative of the Queen, with the suggestion that that be Lady Mary Hastings. Pisemsky was to meet Lady Mary and report back to the tsar as to her looks and character. The prospective candidate would have to convert to orthodoxy and could expect the tsar to remove his current wife forthwith should she (Lady Mary) accept and Elizabeth I approve. The implications for these new proposals might well have been deeply unfavourable for the young Huntingdon, but it had far greater importance in military terms - a formal military alliance would bring England into a war with Poland. ${ }^{110}$ There is no evidence to suggest that Lady Mary had any desire to go to Russia, but Elizabeth played along with proceedings. The English terms were to get back the monopoly privileges that the Muscovy company had so enjoyed previously. It was also the case that although Ivan with his many wives and reputation was hardly a credible match for a lady of the English court and relation of the Queen, Elizabeth could hardly 'hold it against the Czar that he sought [another] ...

102 The National Archive, 70/147, fol. 413 r. -416 v.

103 British Library, Egerton MS 2790, fol. 178 r. - 180 r., d. 1577; British Library, Cotton MS Nero B XI, fol. 349 r. -354 v.

104 British Library, Cotton MS Nero B XI, fol. 349 r. - 354 v., d. 1608; H. Troyat, Ivan, 231; I. Grey, Ivan, 239.

105 I.I. Lubimenko, “Correspondence of Queen Elizabeth,” 534; K. Mayers, North-East Passage, 125.

106 G. Goodwin, and M. Bevan, "Robert, Jacob (d. 1588)," in Oxford Dictionary of National Biography.

107 A. Pavlov, and M. Perrie, Ivan, 196-197; H. Troyat, Ivan, 231; I. Grey, Ivan, 242; The National Archive, PRO 22/60, fol. 5 r. - v.

108 O. Dmitrieva, "The First Hundred Years," 21.

109 I. De Madariaga, Ivan, 343-344; The National Archive, SP 102/49, fol. 2 r. - v.

110 J. Kasprzak, "A Riddle of History: Queen Elizabeth I and The Albertus Laski Affair," The Polish Review, no. 14 (1969): 64-65; H. Troyat, Ivan, 231. 
spouse while still married' given Henry VIII's legacy. ${ }^{111}$ The English court went along with the plan, at least in pretence, in order to support their mercantile community. ${ }^{12}$ Negotiations dragged on and on without success. Ivan continued to pursue the dream of an English alliance and marriage, while Elizabeth continued to press for a return to 'exclusive privileges' for her merchants in Russia. ${ }^{113}$ Neither were successful, but talks lasted well into 1584 and were only brought to a halt with the death of the Tsar. For the Elizabethan mercantile community focussed on Russia, the 'death of Ivan the Terrible ... finally laid to rest the company's hopes of restoring its former status.' 114 The passing of the tsar also saw the end of the most Anglophile tsar there would ever be. No other monarch ever looked to England in quite the same way, nor formally received 'asylum' even if not quite as he would have liked. One must remember that Nicholas II the last tsar of Russia was not in the end provided asylum by Lloyd George's government and George V of England following the Russian Revolution. ${ }^{115}$ English merchants have never had since or are likely to ever have monopoly trading rights in Russia. The open communication of the two monarchs was also staggering when seen in contrast to the leaders that would follow, and all the more so in the geopolitical landscape of the twentyfirst century.

Historians agree that the Tsar sought out a marriage to a relation of Queen Elizabeth I in the 1580s. Perhaps these were the ramblings of an ageing and dying monarch, that was in some ways 'mad' and deeply troubled, although the length of the negotiations suggest that this was not a fleeting thought. What is surprising is that if the tsar looked to an English match in the 1580s, that it was not towards Queen Elizabeth, unless he had already explored that option. Nothing about the tsar would suggest that he would settle for second best and it was well-known that Elizabeth I was unmarried. It would therefore make much more sense that having proposed a union to Elizabeth I in the late 1560 s and early 1570s, and been rejected, he thus ten years later, knowing that he could get nowhere with the Queen, tried for the next best thing, a close relation of the monarch. This hypothesis fits more readily with the sequence of events.

We do not have formal documentation to suggest he ever did propose to Elizabeth I, other than Randolph's communique to Cecil, but following the hypothesis above, it seems far from improbable. Indeed, it would have been in keeping with formal alliances in the early modern world, that were often sealed with the union of marriage. When this is coupled with his 1580s desire for an English match, it is too easy to dismiss claims of a marriage proposal from Ivan in the 1560s.

Unfortunately, this period is riddled with a lack of evidence - with record destruction from fire (Moscow of course suffered a tremendous fire in 1571 at the hands of Crimean invaders), and we can never recreate personal conversations unless they have been recorded in one way or another by a clerk or a diary account. This article would therefore suggest that historians should be less dismissive of the idea of a late $1560 \mathrm{~s}$,

\footnotetext{
111 H. Troyat, Ivan, 232-233; B. Bobrick, Fearful Majesty, 327-329; R.G. Skrynnikov, Ivan, 176.

112 I.I. Lubimenko, "Correspondence of Queen Elizabeth," 529.

113 O. Dmitrieva, "The First Hundred Years," 21.

114 Idem.

115 H. Rappaport, The Race to Save the Romanovs.
} 
early 1570 s marriage alliance proposal from Ivan to Elizabeth. This is not to argue that it was ever realistically considered in England, and may well explain the lack of surviving evidence - a private conversation from Jenkinson to the Queen - but it not beyond the realms of consideration that one was made. Then in the 1580 s the next proposal was not to the Queen, but to one of her relations and this too was received in unfavourable terms.

This article has shown that a marriage proposal may well have been made by Ivan the Terrible to Elizabeth I. That in itself shows the considerable ambitions of the Russian tsar and his desire for the most favourable of diplomatic relations with Elizabethan England. Was it ever likely that Elizabeth would accept such a proposal? It seems most improbable that she would ever have seriously considered it. It was not the language that was the problem, it was personality and governance. Elizabeth took counsel, Ivan did not; Elizabeth 'consulted widely on the choice of councilors,' Ivan did not consult; the Elizabethan council 'was not homogenous, but it was reasonably harmonious and it was characterized by a profound degree of mutual trust between the Queen and at least the inner ring of her councilors,' Ivan trusted almost no one and in a state of mental unrest and fear set-up the Oprichnina. The young queen faced misogyny and 'sneer[s] at [her so called] feminine faults and foibles' to those 'she broke or blocked their careers,' they 'never got very far.'116

With fear of this in her mind and memories of the imbalance of rule with her sister and Philip II, from the very beginning of her reign Elizabeth set out her disinclination to "matrimoniale.' ${ }^{117}$ It is not too far removed to suggest that whilst the enjoyment of courting and courtship was all to the good, Elizabeth also feared the 'role-reversal of marriage,' by remaining unmarried she maintained power. Ivan's letters when in anger to the Queen, are particularly misogynistic ${ }^{118}$ - such a ruler, such a man would never have got far in a royal courtship with Elizabeth Tudor. ${ }^{119}$ It is clear, that Ivan IV was never going to succeed in marrying Gloriana, but he did not know that. That he should have wished to marry, and indeed if not Elizabeth I, then another English royal relation, is important for the study of Anglo-Russian relations in the Elizabethan period and realpolitik more widely in the early modern world.

\section{Why did a formal alliance come to nought - A missed opportunity?}

Ivan IV, for all of his tyrannical rule in Russia, his expansion of empire, his endless marriages, and foreign wars, sought albeit with a gap in the 1570 s a more favourable diplomatic relationship with England than has ever been seen since, from a Russian ruler. This was the zenith for Anglo-Russian relations - a unique moment in trade too in which English merchants had monopoly rights in Russian territory.

The failure of any form of marriage alliance, either to the Queen or to a relation of Elizabeth I, or a military alliance of proper standing, perhaps rested fundamentally in the imbalance of the needs of the two countries. To Ivan, England's arrival on the diplomatic scene at his court rested on trade and not war - and in that, England was almost unique for the tsar as a friendly power. It was a refreshing beginning. For En-

116 E. Starkey, Elizabeth, 309-311; C.J. Halperin, "Ivan IV as Autocrat," 212.

117 British Library, Royal MS 13 B I, fol. 26 r. - v.; fol. 20 r. - v.

118 E. Keenan, "Ivan the Terrible and His Women," 326.

119 D. Starkey, Elizabeth, 309-310. 
gland, however, Russia was part of a growing trading horizon, the relationship was one of many new building blocks being forged by exploration around the world. Muscovy was important for the English, but not in the special way that Ivan viewed England. Russia was still perceived as a distant land and at no point did anyone actually think of a marriage alliance as particularly credible. Hughes sums up something of the xenophobia that western eyes had of Ivan's new eastern empire

a 'barbarous' kingdom on the fringes of Christendom, which as recently as 1480 had claimed independence from the Mongol khans, whose ancestors had conquered most of the Russian lands in the thirteenth century. ${ }^{120}$

Anglo-Russian diplomatic relations continued after Ivan's death, but as the Muscovy company would discover, the late Tsar had been a particular Anglophile and no new monarch would ever treat English arrivals in such favourable terms - his death in 1584 'laid to rest the company's hopes of restoring its former [monopoly] status.' ${ }^{121}$ In that regard this was a missed opportunity for an international alliance that might have cemented England's trading position as superior to all other competitors, stretching from Archangel to Astrakhan and all the way to Siberia. ${ }^{122}$ Nevertheless, in terms of impact, the Elizabethan years saw the growth of the Muscovy Company from a small trading outpost to an important part of England's burgeoning commercial empire the English trading community of the Muscovy enterprise would exist right up until the fall of the Romanovs. English trade in Russia, foreshadowed the East India Company, and would be the benchmark for the subsequent remarkable mercantile ventures, that laid the foundation for England and later Britain's economic prosperity. ${ }^{123}$

\section{Conclusions}

This article has revealed from the surviving contextual history when coupled with a small, but substantive piece of ambassadorial correspondence, that a marriage proposal may well have been made by Ivan IV to Elizabeth I. It was certainly talked of in diplomatic circles. This is of considerable significance for the study of Anglo-Russian relations in the early modern world and for Ivan IV's actions towards England. The differences and motivations between the two monarchs and countries were extensive, not least in concepts of rule and hegemony, for the Tsar even pointed out to the English queen, 'that her power was limited not only by the nobility', but also by her most lowly of subjects. ${ }^{124}$ Nevertheless, as Bogatyrev asserts, perhaps we should view much of Ivan's actions through the lens of 'dynastic politics', a remarkably similar perspective to that of the Tudor court. ${ }^{125}$

Рукопись поступила: 23 апреля 2019 г.

Submitted: 23 April 2019

\footnotetext{
${ }^{120}$ L. Hughes, "Russia," 295.

121 O. Dmitrieva, "The First Hundred Years," 21.

122 R.G. Skrynnikov, "Ermak’s Siberian Expedition," Russian History, no. 13 (1986): 1-39.

123 K. Mayers, North-East Passage, 138-41.

124 A. Pavlov, M. Perrie, Ivan, 87.

125 S. Bogatyrev, 'Reinventing the Russian Monarchy,' 292.
} 


\section{References}

Abramova, N. "English Silver of the Sixteenth and Seventeenth Centuries in the Kremlin." In Britannia and Muscovy: English Silver at the Court of the Tsars, 36-45. New Haven, Connecticut: Yale Centre for British Art Publ., 2006.

Andrew, C. The Secret World: A History of Intelligence. London: Penguin Publ., 2018.

Alford, S. London's Triumph: Merchant Adventurers and the Tudor City. London: The Spectator Publ., 2017.

Alsop, J. “The Revenue Commission of 1552.” The Historical Journal, no. 22 (1979): 511-533.

Bobrick, B. Fearful Majesty: The Life and Reign of Ivan the Terrible. Montpelier, Vermont: Russian life books Publ., 2014.

Bogatyrev, S. "Bronze Tsars: Ivan the Terrible and Fedor Ivanovich in the Décor of Early Modern Guns." The Slavonic and East European Review, no. 88 (2010): 48-72.

Bogatyrev, S. "Reinventing the Russian Monarchy in the 1550s: Ivan the Terrible, the Dynasty, and the Church." The Slavonic and East European Review, no. 85 (2007): 271-293.

Beem, C., and Levin, C. "Why Elizabeth Never Left England." In The Foreign Relations of Elizabeth I, 3-26. New York: Palgrave Macmillan Publ., 2011.

Bertolet, A.R. "The Tsar and the Queen: "You Speak a Language that I Understand Not." In The Foreign Relations of Elizabeth I,101-124. London: Springer Publ., 2011.

Black, J. The Hanoverians: The History of a Dynasty. London: Humbledon Publ., 2004.

Bullock, A. Hitler and Stalin: Parallel Lives. London: Harper Collins Publ., 1991.

Clarkson, J.D. A History of Russia. London: Random House Publ., 1961.

Crosby, A.J. Calendar of State Papers Foreign: Elizabeth, 1569-1571. London: Her Majesty's Stationery Office Publ., 1874.

Grey, I. Ivan The Terrible. London: Hodder \& Stoughton Publ., 1964.

Cressy, D. "Saltpetre, State Security and Vexation in Early Modern England." Past and Present, no. 212 (2011): 74-111.

Davies, G. "The Expansion of Trade and Finance, 1485-1640." In History of Money, 176-237. Cardiff: University of Wales Press Publ., 2002.

De Madariaga, I. Ivan the Terrible: First Tsar of Russia. New Haven: Connecticut Publ., 2005.

Doran, S. Monarchy and Matrimony. The courtships of Elizabeth I. London: Routledge Publ., 1996.

Doran, S. Elizabeth I and Her Circle. Oxford: Oxford University Press Publ., 2015.

Doran, S. Elizabeth I and Foreign Policy, 1558-1603. London: Routledge Publ., 2000.

Dmitrieva, O. "Introduction: "The Golden Chain of Traffic": The First Hundred Years of AngloRussian Relations." In Britannia and Muscovy: English Silver at the Court of the Tsars, 12-35. New Haven, Connecticut: Yale Centre for British Art Publ., 2006.

Dmitrieva, O., and Abramova, N. Britannia and Muscovy: English Silver at the Court of the Tsars. New Haven, Connecticut: Yale Centre for British Art Publ., 2006.

Evans, J. Tudor Adventures. An Arctic Voyage of Discovery: The Hunt for the Northeast Passage. New York: Pegasus Publ., 2014.

Filyushkin, A. Ivan the Terrible: A Military History. Barnsley: Frontline Books Publ., 2008.

Graham, H.F. "How do we know what we know about Ivan the Terrible? (A Paradigm)." Russian History, no. 14 (1987): 179-198.

Gralya, I. Ivan Mikhaylov Viskovatyy: Kar'yera gosudarstvennogo deyatelya v Rossii XVI v. Moscow: Radiks Publ., 1994 (in Russian).

Gross, G. "From London to Moscow coronations: perceptions of monarchy," Systems psychology and sociology, no. 2 (26) (2018): 97-110.

Halperin, C.J. "Ivan IV as Autocrat (Samoderzhets)," Cahiers du Monde russe, no. 55 (2014): 197-213.

Halperin, C.J. Ivan the Terrible: Free to Reward \& Free to Punish. Pittsburgh, Pennsylvania: University of Pittsburgh Press Publ., 2019.

Hakluyt, R. The Principall Navigations... London: G. Bishop and R. Newberie Publ., 1589.

Hamel, J. England and Russia. London: Bentley Publ., 1968. 
Hatton, R. George I. New Haven, Connecticut: Yale University Press Publ., 2001.

Hellie, R. "Sir Jerome Horsey (d. 1626)." In Oxford Dictionary of National Biography, https://www. oxforddnb.com/view/10.1093/ref:odnb/9780198614128.001.0001/odnb-9780198614128-e13813; jsessionid=B0378C24D437EE29B60701AA056C5206.

Hoak, D. "The Secret History of the Tudor Court: The King's Coffers and the King's Purse, 1542-1553." Journal of British Studies, no. 26 (1987): 208-231.

Hughes, L. "Russia: The Courts at Moscow and St. Petersburg.1547-1725." In The Princely Courts of Europe: Ritual, Politics and Culture Under the Ancien Régime 1500-1750, 295-313. London: Seven Dials Publ., 1999.

Hunt, P. “Ivan IV's Personal Mythology of Kingship.” Slavic Review, no. 52 (1993): 769-809.

Huttenbach, H.R. "New Archival Material on the Anglo-Russian Treaty of Queen Elizabeth I and Tsar Ivan IV," The Slavonic and East European Review, no. 49 (1971): 535-549.

Keenan, E.L. "Ivan the Terrible and His Women," Russian History, no. 37 (2010): 322-359.

Kleimola, A.M., and Lenhoff, G.D. Moskovskaya Rus' (1359-1584): kul'tura i istoricheskoye samosoznaniye. Moscow: ITS-Garant Publ., 1997 (in Russian).

Lubimenko, I. "The Correspondence of Queen Elizabeth with the Russian Czars," The American Historical Review, no. 19 (1914): 525-542.

Lubimenko, I. "A Suggestion for the Publication of the Correspondence of Queen Elizabeth with the Russian Czars." Transactions of the Royal Historical Society, no. 9 (1915): 111-122.

MacCulloch, D. The Boy King: Edward VI and the Protestant Reformation. Berkeley, California: University of California Press Publ., 2002.

Martin, N. "Princess Cecilia's Visitation to England, 1565-1566." In The Foreign Relations of Elizabeth I, 27-44. New York: Palgrave Macmillan Publ., 2011.

Mayers, K. North-East Passage to Muscovy: Stephen Borough and the First Tudor Explorations. Stroud: Sutton Publ., 2005.

Montefiore Sebag, S. The Romanovs. London: Weidenfeld a. Nicolson Publ., 2016.

Montefiore Sebag, S. Stalin: The Court of the Red Tsar. London: Weidenfeld \& Nicolson Publ., 2003.

Morgan, E.D., and Coote, C.H. Early Voyages and Travels to Russia and Persia by Anthony Jenkinson ... with Russia ... by way of the Caspian Sea. London: Hakluyt Society Publ., 1886.

Miller, D.B. "Creating Legitimacy: Ritual, Ideology, and Power in Sixteenth-Century Russia." Russian History, no. 21 (1994): 289-315.

Oman, C. The English Silver in the Kremlin, 1557-1663. London: Methuen Publ., 1961.

Oldland, J. "The allocation of merchant capital in early Tudor London." The Economic History Review, no. 63 (2010): 1058-1080.

Pavlov, A.M. Ivan the Terrible: Profiles in Power. London: New York University Press Publ., 2013.

Perrie, M. "The Popular Image of Ivan the Terrible." The Slavonic and East European Review, no. 56 (1978): 275-286.

Pipes, R. Russia under the Old Regime. London: John Murray Publ., 1995.

Pryor, F. Elizabeth I: Her Life in Letters. London: British Library Publ., 2003.

Rappaport, H. The Race to Save the Romanovs: The Truth Behind the Secret Plans to Rescue Russia's Imperial Family. London: St. Martin's press Publ., 2018.

Rappaport, H. Caught in the Revolution: Petrograd 1917. London: Windmill Books Publ., 2016.

Raymond Beazley, C. "Exploration under Elizabeth, 1558-1603." Transactions of the Royal Historical Society, no. 9 (1895): 119-165.

Skrynnikov, R.G. Ivan the Terrible. Florida: Academic International Press Publ., 1981.

Starkey, D. Elizabeth: Apprenticeship. London: Vintage Publ., 2000.

Stout, F.J. Exploring Russia in the Elizabethan commonwealth: The Muscovy Company and Giles Fletcher, the elder (1546-1611). Manchester: Manchester University Press Publ., 2015.

Tolstoy, G. Pervyye sorok let obshcheniya mezhdu Angliyey i Rossiyey 1553-1593. St. Petersburg: Tipografiya A. Transhelya Publ., 1875 (in Russian).

Troyat, H. Ivan the Terrible. New York: Dorset Press Publ., 1987. 
Turnbull, W.B. Calendar of State Papers Foreign: Edward VI 1547-1553. London: Her Majesty's Stationery Office Publ., 1861.

Uspenskiy, B.A. "Enthronement in the Russian and Byzantine Traditions." In Tsar and God, 153-174. Boston, Massachusetts: Academic Studies Press Publ., 2012.

Wortman, R.S. Scenarios of Power: Myth and Ceremony in Russian Monarchy from Peter the Great to the Abdication of Nicholas II. Princeton, New Jersey: Princeton University Press Publ., 2006.

Welch, F. The Imperial Tea Party. Family, Politics and Betrayal: The Ill-fated British and Russian Royal Alliance. London: Short Books Publ., 2018.

Service R. The Last of the Tsars: Nicholas II and the Russian Revolution. London: Pan Books Publ., 2017.

Skrynnikov, R.G. “Ermak’s Siberian Expedition.” Russian History, no. 13 (1986): 1-39.

Zagorodnaya, I. "English Diplomats at the Court of the Tsars." In Britannia and Muscovy: English Silver at the Court of the Tsars, 176-195. New Haven, Connecticut: Yale Centre for British Art Publ., 2006.

\section{Информация об авторе / Information about the author}

Джордж Гросс, доктор теологических наук George W.C. Gross, PhD in Theology, Visiting $(\mathrm{PhD})$, научный сотрудник Королевского колледжа Лондона. Является одним из организаторов семинара «Религиозная история Британии, 1500-1800», проводимого в Институте Research Fellow at King's College London University. He is a co-convener at 'The Religious History of Britain, 1500-1800' seminar held at исторических исследований в Лондоне. 